\title{
INCREASED NATURAL KILLER ACTIVITY DOES NOT PREVENT PROGRESSION OF EXPERIMENTAL KALA-AZAR
}

\author{
Alexandrina SARTORI(1), Ramon KANENO(1), Nelson BARUZZI(2) \& Maria Terezinha Serrão PERAÇOLI(1)
}

\begin{abstract}
SUMMARY
Kala-azar is the visceral form of leishmaniasis and it is caused by intracellular parasites from the complex Leishmania donovani. Golden hamster (Mesocricetus auratus) infected with Leishmania donovani develop a disease very similar to human Kalaazar. There is conspicuous hipergammaglobulinaemia and their T cells do not respond to stimulation with parasite antigens. We used this experimental model to evaluate the natural killer (NK) activity during the initial phase of the disease. Outbred hamsters infected by intravenous route with $5.10^{6}$ amastigotes of $L$. donovani $1 \mathrm{~S}$ showed a concurrent increase in the spleen weight and in the spleen cell number. Using the single cell assay we detected a significant increase in the percentage of NK effector cells on the $4^{\text {th }}$ day of infection. Imprints from spleen and liver showed at days 14 and 28 a significant increase in the parasite burden. These results show that the increased NK activity in the beginning of the infection was not able to restrain the progression of the disease in this experimental model.
\end{abstract}

KEYWORDS: Kala-azar; Leismania donovani; Natural killer activity.

\section{INTRODUCTION}

Kala-azar is the visceral form of leishmaniasis and it is caused by the intracellular parasites from the Leishmania donovani complex. The induction of Th1 effector cells capable of gamma IFN (IFN $\gamma$ ) production for activation of macrophages to a microbicidal state is necessary to eliminate these parasites ${ }^{22}$. The development of Th1 cells had been initially associated with interleukin-12 (IL-12) in a murine model of listeriosis ${ }^{10}$. More recently it was demonstrated that IL-12 is produced by macrophages in the early response to many other infectious agents, particularly bacteria and protozoa ${ }^{21,26}$. This IL-12 induces production of IFN $\gamma$, first mainly by NK cells and then by $\mathrm{T}$ cells. This early response is important for the activation of the phagocytic cell system as a first line of defense against infection, but the IL-12 produced in this early phase, often acting in combination with the induced IFN $\gamma$, is also required for optimal generation of Th1 cells ${ }^{25}$. In addition to IFN $\gamma$ production, NK cells also act as effector cells of the natural resistance by direct lysis of the pathogen, as shown with Cryptococcus neoformans ${ }^{12}$ or by lysis of infected cells as shown for Mycobacterium tuberculosis infected human monocytes $^{28}$.

Active visceral leishmaniasis is associated with immune dysregulation including very high levels of immunoglobulins ${ }^{7}$, splenomegaly, negative skin test for Leishmania antigen ${ }^{15}$ and absence of proliferative response by peripheral blood mononuclear cells stimulated with parasite antigens ${ }^{19}$. Indian kala-azar patients have normal numbers of peripheral blood NK cells but impaired functional activity due to decreased binding and lysis of target cells ${ }^{13}$. In addition, plasma from patients with $L$. donovani infection was shown to reduce the in vitro natural killer activity of normal human peripheral blood mononuclear cells ${ }^{14}$. On the other hand NK cells from non-Leishmania- exposed individuals could respond in vitro by proliferation and IFN $\gamma$ production to $L$. aethiopica stimulation ${ }^{1}$.

In mice experimentally infected with $L$. donovani $\mathrm{NK}$ cells may contribute to parasite elimination ${ }^{11}$. Since the Syrian hamster is a good model for the study of progressive visceral leishmaniasis caused by $L$. donovani, we used these animals to further investigate the involvement of NK cells, by assessing their lytic activity, during the initial phase of this infection.

\section{MATERIAL AND METHODS}

Animals: Female outbred hamsters (Mesocricetus auratus) 8-12 weeks old, were obtained from the Central Animal Facility at the São Paulo State University (UNESP), Botucatu, São Paulo. Pelleted food and water were available ad libitum.

Parasites: L. donovani $1 \mathrm{~S}$, kindly donated by Dr. Dennis Dwyer (Laboratory of Parasitology, NIH, Bethesda, MD, USA) was maintained by in vivo passage of the amastigotes from hamster to hamster. Amastigotes were obtained from infected spleens by differential centrifugation.

\footnotetext{
(1) Department of Microbiology and Immunology, Institute of Biological Sciences, São Paulo State University (UNESP), Botucatu, SP, Brazil. (2) Hematology Center, Medical School of UNESP, Botucatu, SP, Brazil.

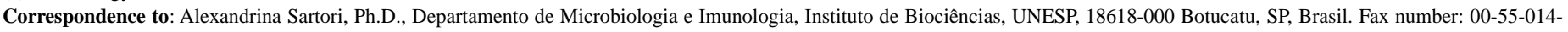
8213744. Phone number: 00-55-014-820-6058 E-mail: sartori@ibb.unesp.br.
} 
Experimental infections: Twenty four hamsters were infected by intracardiac route with $5.10^{6}$ amastigotes in $0.1 \mathrm{ml}$ of phosphate-buffered salt solution (PBS), $\mathrm{pH}$ 7.2. The same number of hamsters were kept non-infected to be used as controls. Groups of 4 infected and 4 noninfected animals were sacrificed at 1, 2, 4, 7, 14 and 28 days postinoculation and their spleens were used to evaluate the following parameters: spleen weight, number of splenic cells, NK cell activity and parasite burden. Liver was also collected for parasite burden evaluation.

Parasite burden: Parasite burden was determined by examining Giemsa-stained impression smears from livers and spleens as previously described ${ }^{4}$, and calculated according to the formula:

Total LDU $=\frac{\text { number of amastigotes }}{\text { number of host-cell nuclei }} \times$ organ weight $(\mathrm{mg}) \times 2.10^{5}$

Single cell cytotoxicity assay: The human erythroleukemia cell line K562 was maintained as a suspension culture in medium RPMI 1640 (Gibco Laboratories, Grand Island, NY) supplemented with $2 \mathrm{mM} \mathrm{L-}$ glutamine, $40 \mathrm{ug} / \mathrm{ml}$ gentamicin and $10 \%$ heat-inactivated fetal calf serum (complete medium). Cells were subcultured twice a week and at the day before the assay. Viability was assessed by trypan blue exclusion. K562 cells were previously tested and were highly susceptible to hamster spleen-cell cytotoxicity ${ }^{24}$.

Effector cells were prepared from spleen of normal and infected hamsters. The spleens were asseptically removed and cell suspensions prepared by teasing the material through a stainless-steel sieve in cold RPMI 1640 medium. After to be washed twice in cold RPMI cells were adjusted to $3.10^{6} / \mathrm{ml}$ and adherent cells were depleted by incubation on plastic Petri dishes (n.3003, Falcon, Oxnard, California, USA) at $37^{\circ} \mathrm{C}$ for $60 \mathrm{~min}$. Non-adherent spleen cells and K562 cells were used as effector and target cells, respectively. The single-cell cytotoxicity assay on poly-L-lysine (PLL) coated coverslips was performed as already described for the Syrian hamster ${ }^{17}$.

The number of target/binding cells (TBC) and cytotoxic effector cells were calculated as previously described ${ }^{29}$. Spontaneous target cell death was determined on lymphocyte-free control coverslips by scoring the fraction of dead (trypan blue stained) target cells in 300 cells. The percentage of lymphocytes bound to target cells was determined by counting 500 lymphocytes (\%TBC). The fraction of conjugates containing dead target cells was determined by scoring 100 conjugates. The fraction of target-cell binding lymphocytes that were cytotoxic (A) was calculated as $A=B-(B x C)$, where $B$ is the fraction of conjugates containing dead target cells and $\mathrm{C}$ is the fraction of spontaneously dead target cells. The percentage of NK-effector cells present in the samples was calculated as A x \% TBC.

Statistical analysis: Student's t-test was performed to determine the statistical significance of data.

\section{RESULTS}

Spleen weight alteration - Hamsters infected with $5.10^{6}$ amastigotes of L. donovani $1 \mathrm{~S}$ showed, from the $7^{\text {th }}$ day of infection on, increasing spleen weight compared with non infected controls. The differences
(Figure 1a) were considered statistically significant on days 7, 14 and 28 of infection $(\mathrm{p}<0.05)$. On the $28^{\text {th }}$ day of infection, last point to be evaluated, there was a striking difference, being the spleen from infected hamsters 3.8 times heavier than the correspondent controls.

Quantitation of splenic cells - Spleens from normal and infected hamsters were removed and cell suspensions prepared by teasing the material through a stainless steel sieve in RPMI medium. The total number of cells was counted in a Neubauer chamber. Figure 1b clearly
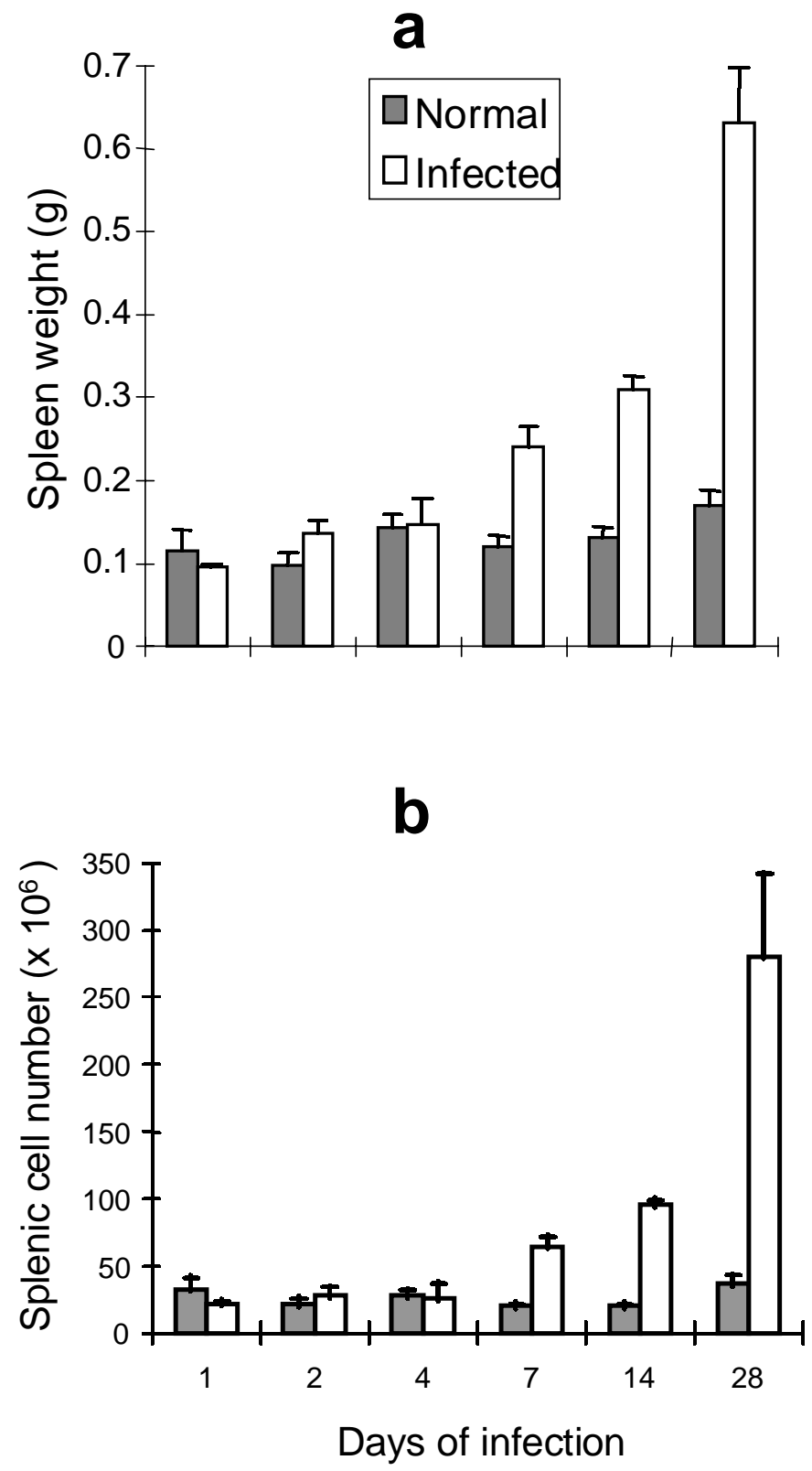

Fig 1. Spleen alterations during leishmanial infection. Spleen weight (a); splenic cell number (b). Control non infected hamsters ( $\square$ ), infected hamsters ( $\square$ ). Values represent the mean + standard error of the mean for four animals. Differences in spleen weight and spleen cell number between infected and non-infected hamsters were significant $(\mathrm{p}<0.05)$ on days 7 , 14 and 28 after infection. 
shows an increasing difference between the average number of cells from infected and normal hamsters. At the $14^{\text {th }}$ and $28^{\text {th }}$ days postinfection these differences were very pronounced, being highly significant ( $\mathrm{p}=$ 0.0013 and $\mathrm{p}=0.01$ respectively). The number of splenic cells at the $28^{\text {th }}$ day was 7.8 times higher compared with the control animals.

Evaluation of NK cell activity - The results of NK cell activity, evaluated by the single cell assay, are shown on Table 1 . The percentage of lymphocytes with the ability to bind NK-sensitive target cells did not undergo any significant change during the infection. However the percentage of conjugates in which lymphocytes killed the target cells and the percentage of NK-effector cells in the non-adherent splenic population were significantly higher on the $4^{\text {th }}$ day of infection $(p=$ $0.008)$. After the $4^{\text {th }}$ day of infection the cells from infected animals kept higher ability to form dead conjugates and higher NK-effector cells in comparison with control animals. These differences were, nevertheless, less expressive than the one observed at the $4^{\text {th }}$ day of infection.

Table 1

Frequency of lymphocytes forming conjugates and NK-effector cells in the spleen of hamsters experimentally infected with $L$. donovani

\begin{tabular}{ccccc}
\hline $\begin{array}{l}\text { Days of } \\
\text { infection }\end{array}$ & Groups $\%$ of lymphocytes & $\begin{array}{c}\text { \% of conjugates } \\
\text { forming } \\
\text { conjugates* }\end{array}$ & $\begin{array}{c}\% \text { of } \\
\text { targets\# }\end{array}$ & NK-effector \\
\hline 1 & Control & $9.16(1.36)$ & $19.95(3.51)$ & $1.80(0.42)$ \\
& Infected & $8.86(0.58)$ & $22.69(5.44)$ & $2.0(0.57)$ \\
\hline 2 & Control & $10.63(1.46)$ & $13.11(2.01)$ & $1.36(0.07)$ \\
& Infected & $12.55(4.23)$ & $17.70(8.71)$ & $2.05(0.72)$ \\
\hline 4 & Control & $10.53(2.36)$ & $17.93(5.26)$ & $1.76(0.29)$ \\
& Infected & $10.15(1.57)$ & $31.49(3.89)$ & $3.07(0.45)$ \\
\hline 7 & Control & $10.15(1.55)$ & $16.23(2.45)$ & $1.61(0.08)$ \\
& Infected & $11.33(1.79)$ & $21.58(9.20)$ & $2.42(1.03)$ \\
\hline 14 & Control & $9.52(2.28)$ & $17.56(3.16)$ & $1.60(0.20)$ \\
& Infected & $9.38(0.92)$ & $26.10(6.85)$ & $2.46(0.80)$ \\
\hline 28 & Control & $11.29(2.58)$ & $16.98(4.47)$ & $1.79(0.25)$ \\
& Infected & $9.18(3.64)$ & $26.81(2.95)$ & $2.48(1.10)$ \\
\hline
\end{tabular}

(*)Calculated per 500 lymphocytes;

(\#)Calculated per 100 conjugates. Spontaneously dead targets were always below $2 \%$.Values represent the mean for four animals. In parentheses is shown the standard deviation.

Splenic and hepatic parasite burden - To establish the extension of the parasitism in the liver and in the spleen, imprints from these organs were microscopically assessed. Figure 2 shows the parasite burden in the spleen and liver. After 1 day of infection only $1 \%\left(0.052 \times 10^{6}\right.$ parasites) of the total inoculum was retained by the spleen in comparison with $76 \%$ (3.8 $\times 10^{6}$ parasites) retained by the liver. The number of parasites in both organs highly increased only after 14 days of infection.

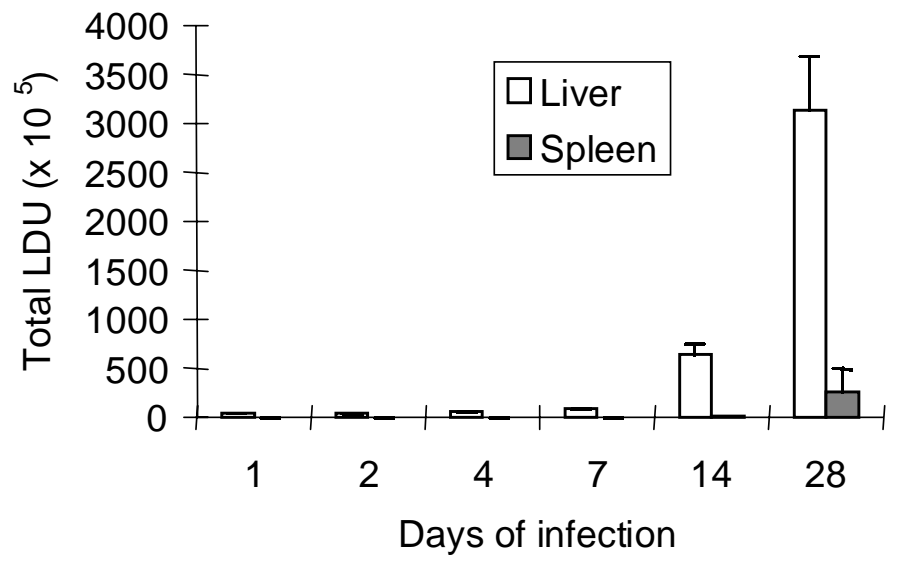

Fig 2. Parasite burden during leishmanial infection. Giemsa-stained impression smears from liver and spleen were microscopically assessed. Results represent the mean + standard error of the mean for four animals.

\section{DISCUSSION}

NK cells are able to respond rapidly, non-specifically, to the presence of infectious microorganisms. Together with phagocytes, NK cells represent the first line of defense against infection. This defense can take the form of direct lysis of the pathogen or involve lysis of infected cells. However, in many cases it is the production of IFN $\gamma$ and the consequent IFN $\gamma$ mediated macrophage microbicidal activity that is probably of central importance in resistance ${ }^{23}$.

In the present work we evaluated the NK activity in Syrian hamsters experimentally infected with $L$. donovani. This model seems to mimetize very well the progressive human visceral leishmaniasis ${ }^{16}$.

Hamsters infected by intracardiac route with $5.10^{6}$ amastigotes of $L$. donovani $1 \mathrm{~S}$ showed an increased spleen weight compared with control non-infected animals. This alteration that begun on day $7^{\text {th }}$ postinfection, became more pronounced in the course of the disease and attained its maximum after 28 days of infection, the last period evaluated in this study. A very similar pattern was observed when the number of splenic cells was counted in the course of the infection. From the $7^{\text {th }}$ day on we detected an increasing number of cells that peaked on the $28^{\text {th }}$ day. This splenic hipertrophy is a classical description both in human and experimental kala-azar ${ }^{9}$ and could be attributed to both monocyte recruitment ${ }^{20}$ and polyclonal activation of $\mathrm{B}$ cells due to parasite components ${ }^{5}$. However, this impressive increase in the splenic cell number through the infection was not associated to any alteration on the ability of splenic lymphocytes to recognize and bind NK-sensitive cells. As the single cell assay used in this study evaluates the percentage of nonadherent cells that bind to NK-sensitive cells, this finding could suggest that NK cells increased in number in a proportional way to the increase of the other non-adherent cells in the spleen. However, the percentage of conjugates in which lymphocytes had killed cells and the percentage of NK-effector cells in the infected animals were significantly higher after $96 \mathrm{~h}$ of infection. These results show an activation of NK cells in the beginning of the infection. Althought our work had not evaluated the cause of this activation, the cytokine IL-12 would be a good candidate 
due to its well established activation effect on NK cells ${ }^{6}$. In addition, a recent report shows that IL-12 is required for NK cell activation and subsequent $\mathrm{Th} 1$ development in $\mathrm{C} 3 \mathrm{H}$ mice experimentally infected with L. major $^{21}$. Also the ability of amastigotes to induce IL-12 production from bone-marrow-derived macrophages in vitro was demonstrated by either direct measurement or indirectly through IFN $\gamma$ release using SCID splenocytes ${ }^{18,27}$. From the $7^{\text {th }}$ day to the $28^{\text {th }}$ day of infection the NK activity in the infected animals was still significantly higher compared with the control animals, even though not as much as on the $4^{\text {th }}$ day. It is possible that this increased NK cell activity had mediated an early resistance to the L. donovani infection, mainly in the spleen, keeping a low number of parasites, during the first two weeks of the disease. This increased NK activity, however, was not able to restrain the progression of the disease. The parasite burden from both spleen and liver increased significantly from the $14^{\text {th }}$ to the $28^{\text {th }}$ day of infection.

The progression of the disease, in spite of the significant increase in NK activity could suggest the development of an inefficient specific immune response. This could be the case if inhibitory cytokines such as IL-10 and TGF- $\beta$ would be produced in excess. These two cytokines have been described as potent factors for macrophage deactivation ${ }^{3}$. Besides, IL-10 and TGF- $\beta$ have been reported as factors associated with the pathogenesis in human and experimental leishmaniasis respectively ${ }^{2,8}$.

In conclusion, our results show a clear activation of NK cells during the experimental leishmaniasis in the hamster. However, this increased NK activity was not able to restrain the progression of the disease in the experimental conditions used by us.

\section{RESUMO}

\section{Atividade "natural-killer" aumentada não impede a progressão do Kala-azar experimental}

O Kala-azar é a forma visceral da leishmaniose e é causado pelos parasitas do complexo Leishmania donovani. O hamster dourado (Mesocricetus auratus) infectado com L. donovani desenvolve uma doença bastante similar ao Kala-azar humano, apresentando hipergamaglobulinemia e supressão da resposta imune celular específica. Utilizamos este modelo experimental para avaliar a atividade natural killer (NK) na fase inicial da infecção. Hamsters não isogênicos infectados por via intravenosa com $5.10^{6}$ amastigotas de L. donovani $1 \mathrm{~S}$ apresentaram aumento no peso do baço e no número de células esplênicas. Utilizando o "single cell assay" detectamos um aumento significativo no percentual de células NK efetoras no $4^{\circ}$ dia de infecção. "Imprints" de baço e de fígado mostraram aumento significativo na carga parasitária após 14 e 28 dias de infecção. Os resultados mostram que o aumento da atividade NK, ocorrido no início da infecção, não foi capaz de bloquear a progressão da doença neste modelo experimental.

\section{ACKNOWLEDGMENTS}

The authors sincerely thank the Foundation for the development of UNESP (FUNDUNESP-199/92-DFP/F/CBS) for providing the financial assistance and Paulo Sérgio Ferreira for assistance with the manuscript.

\section{REFERENCES}

1. AKUFFO, H.; MAASHO, K. \& HOWE, R. - Natural and acquired resistance to Leishmania: celular activation by Leishmania aethiopica of mononuclear cells from unexposed individuals is through the stimulation of natural killer (NK) cells. Clin. exp. Immunol., 94: 516-521, 1993.

2. BARRAL, A.; BARRAL-NETO, M.; YONG, E.C. et al. - Transforming growth factor $\beta$ as a virulence mechanism for Leishmania braziliensis. Proc. nat. Acad. Sci. (Wash.), 90: $3442-3446,1993$.

3. BOGDAN, C.; PAIK, J.; VODOVOTZ, Y. \& NATHAN, C. - Contrasting mechanisms for suppression of macrophage cytokine release by transforming growth factor-beta and interleukin-10. J. biol. Chem., 267: 23301-23308, 1992.

4. BRADLEY, D.J. \& KIRKLEY, J. - Regulation of Leishmania population within the host. 1. The variable course of Leishmania donovani infections in mice. Clin. exp. Immunol., 30: 119-129, 1977.

5. BUNN-MORENO, M.M.; MADEIRA, E.D.; MENEZES, J.A. \& CAMPOS-NETO, A. - Hypergammaglobulinaemia in Leishmania donovani infected hamsters: possible association with a polyclonal activation of B cells and with suppression of $\mathrm{T}$ cell function. Clin. exp. Immunol., 59: 427-434, 1985.

6. CHAN, S.H.; PERUSSIA, B.; GUPTA, J.W. et al. - Induction of interferon- $\gamma$ production by natural killer cell stimulatory factor: characterization of the responder cells and sinergy with other inducers. J. exp. Med., 173: 869-879, 1991.

7. CHAVES, J. \& FERRI, R.G. - Immunoglobulins in visceral leishmaniasis. Rev. Inst. Med. trop. S. Paulo, 8: 225-227, 1966.

8. GHALIB, H.W.; PIUVEZAM, M.R.; SKEIKY, Y.A. et al. - Interleukin 10 production correlates with pathology in human Leishmania donovani infections. J. clin. Invest., 92: 324-329, 1993.

9. HOMMEL, M. - The genus of Leishmania: biology of the parasites and clinical aspects. Bull. Inst. Pasteur, 75: 5-102, 1978.

10. HSIEH, C.; MACATONIA, S.E.; TRIPP, C.S. et al. - Listeria-induced Th1 development in $\alpha \beta$-TCR transgenic CD4+ T cells occurs through macrophage production of IL12. Science, 260: 547-549, 1993.

11. KIRKPATRICK, C.E. \& FARREL, J.P. - Leishmaniasis in beige mice. Infect. Immun., 38: 1208-1216, 1982.

12. LEVITZ, S.M.; DUPONT, M.P. \& SMAIL, E.H. - Direct activity of human T lymphocytes and natural killer cells against Cryptococcus neoformans. Infect. Immun., 62: 194202, 1994.

13. MANNA, P.P.; BHARADWAJ, D.; BHATTACHARYA, S. et al. - Impairment of natural killer cell activity in Indian Kala-azar: restoration of activity by interleukin 2 but not by alpha or gamma interferon. Infect. Immun., 61: 3565-3569, 1993.

14. MANNA, P.P.; CHAKRABARTI, G.; BHATTACHARYA, S. et al. - Plasma of Indian Kala-azar patients suppresses natural killer cell activity in vitro. Trans. roy. Soc. trop. Med. Hyg., 88: 247-248, 1994.

15. MANSON-BAHR, P.E.C. - Immunity in Kala-azar. Trans. roy. Soc. trop. Med. Hyg., 55: 550-555, 1961.

16. NICKOL, A.D. \& BONVENTRE, P.F. - Immunosuppression associated with visceral leishmaniasis of hamsters. Paras. Immunol., 7: 439-449, 1985.

17. PERAÇOLI, M.T.S.; FORTES, M.R.P.; PEREIRA DA SILVA, M.F. \& MONTENEGRO, M.R. - Natural killer cell activity in experimental paracoccidioidomycosis of the Syrian hamster. Rev. Inst. Med. trop. S. Paulo, 37: 129-136, 1995. 
18. REINER, S.L.; ZHENG, S.; WANG, Z.; STOWRING, L. \& LOCKSLEY, R.M. Leishmania promastigotes evade interleukin-12 (IL-12) induction by macrophages and stimulate a broad range of cytokines from CD4+ T cells during initiation of infection. J. exp. Med., 179: 447-456, 1994.

19. REZAY, H.R.; ARDEHALI, S.M.; AMIRHAKIMI, G. \& KHARAZMI, A. Immunological features of Kala-azar. Amer. J. trop. Med. Hyg., 27: 1979-1983, 1978.

20. RIDLEY, M.J. \& RIDLEY, D.S. - Monocyte recruitment, antigen degradation and localization in cutaneous leishmaniasis. Brit. J. exp. Path., 67: 209-218, 1986

21. SCHARTON-KERSTEN, T.; AFONSO, L.C.C.; WYSOCKA, M.; TRINCHIERI, G. \& SCOTT, P. - IL-12 is required for natural killer cell activation and subsequent T helper 1 development in experimental leishmaniasis. J. Immunol., 154: 5320-5330, 1995.

22. SCHARTON, T.M. \& SCOTT, P. - Natural killer cells are a source of interferon- $\gamma$ that drives differentiation of CD4+ T cell subsets and induces early resistance to Leishmania major in mice. J. exp. Med., 178: 567-577, 1993.

23. SHER, A.; OSWALD, J.; HIENY, S. \& GAZZINELLI, R.T. - Toxoplasma gondii induces a T-independent IFN- $\gamma$ response in NK cells which requires both adherent accessory cells and TNF- $\alpha$. J. Immunol., 150: 3982-3998, 1993.

24. TEALE, D.M.; REES, E.C.; CLARK, A. \& POTTER, C.W. - Detection and characterization of natural killer cells in Syrian golden hamster. Europ. J. Cancer clin. Oncol., 19: 537-545, 1983.
25. TRINCHIERI, G. - Interleukin-12: a proinflammatory cytokine with immunoregulatory functions that bridge innate resistance and antigen-specific adaptative immunity. Ann. Rev. Immunol., 13: 251-276, 1995.

26. TRIPP, C.S. \& UNANUE, E.R. - Macrophage production of IL-12 is a critical link between the innate and specific immune responses to Listeria. Res. Immunol., 146: 515-519, 1995

27. VARKILA, K.; CHATELAIN, R.; LEAL, L.M.C.C. \& COFFMAN, R.L. - Reconstitution of C.B-17 scid mice with BALB/c T cells initiates a T helper type 1 response and renders them capable of healing Leishmania major infection. Europ. J. Immunol., 23: 262-268, 1993.

28. YOSHIMOTO, T. \& PAUL, W.E. - CD4+ NK1.1+ T cells promptly produce interleukin 4 in response to in vivo challenge with anti-CD3. J. exp. Med., 179: 1285-1295, 1994.

29. WAHLIN, B.; ALSHEIKHLY, A.; PERLAMANN, P.; SCHREIBER, R.D. \& MÜLLEREBERHARD, H.J. - Enumeration and characterization of human killer and natural killer cells by a modified single cell assay. Scand. J. Immunol., 19: 529-539, 1984

Received: 15 January 1999

Accepted: 26 April 1999 